\title{
Evaluation of Gender Difference Influence: Effects of Games on Acquisition of Science Process Skills in Junior Secondary School South East Nigeria
}

\author{
Obiageli Constance Ejilibe ${ }^{1} \quad$ Emmanuel Ikechukwu Nnamonu ${ }^{*}$ \\ Philomena Chinonye Chukwuemeka ${ }^{1}$ Juliana Chukwuma Ifeanyi ${ }^{2}$ \\ Simon Okechukwu Onyishi ${ }^{3} \quad$ Blessing Uchechukwu Onyeidu ${ }^{4}$ \\ 1Department of Biology, Federal College of Education, Eha-Amufu, Enugu State \\ 2Department of Fine Arts, Federal College of Education, Eha-Amufu, Enugu State \\ 3Department of Physics, Federal College of Education, Eha-Amufu, Enugu State \\ 4Department of Home Economics, Federal College of Education, Eha-Amufu, Enugu State
}

\begin{abstract}
The relevance of instructional games has made it an important instructional approach for the teaching and learning of science especially at junior secondary level. The present study was focused on gender difference influence: effects of games on acquisition of science process skills in junior secondary school south east Nigeria. The quasiexperimental design was used for this study. The population of this study consisted of the entire Junior Secondary School, Basic Science students one (JSS 1) of the thirty-five (35) public secondary schools in Enugu Education Zone. The sample for the study was one hundred and sixty (160) Basic Science students and four Basic Science teachers from co-education secondary schools in Enugu Education Zone of Enugu state. Stratified random sampling was employed to obtain the schools used for the study. The instruments used for the study was the Test of Science Process Skills Acquisition Test (TOSPSAT). The instruments were given to four (4) experts in science education, two (2) science educators (measurement and evaluators) and two (2) experienced integrated teachers for face and content validation. The reliability of TOSPSAT was done using Kuder-Richardson formula 20 (K-R 20). The research questions were answered using mean and standard deviation. Analysis of covariance (ANCOVA) was used for testing hypotheses at $\mathrm{P}<0.05$ level of significance. The students taught using game teaching approach had higher mean science process skills acquisition scores in all the skills studied than those taught using conventional method. There was a significant difference in the mean science process skills acquisition scores of subjects exposed to games than those exposed to conventional method. Male and female students exposed to games scored higher in all the science process skills studied. There was no significant difference found in the mean science process skills acquisition scores of male and female students exposed to games. The interaction effect of instructional methods and gender on mean science process skills acquisition scores was not significant. The findings of this implies that students, teachers and curriculum planners should adopt the use of games in teaching and learning processes.
\end{abstract}

Keywords: games, science process skills, gender difference

DOI: $10.7176 / \mathrm{JEP} / 11-15-06$

Publication date:May $31^{\text {st }} 2020$

\section{Introduction}

The traditional didactic approach to teaching - conventional method involves one directional flow of information from the teacher to the learners (Denye and Gbamanja, 1991). It is widely adopted in teaching science in secondary schools but has failed because it is not child-centered learning based (Iloputaife, 1996).

Games as a teaching method have been widely used in teaching (Lawrence, 2006). Instructional game according to Harbor Peter (2001) is a type of game where participants made decision as if they were in actual situations, involving strategies, tactics and initiatives from players. Educational game is an activity where by students use data and skills in a competitive situation. The value of games in teaching and learning cannot be over emphasized (Finely in Umo (2001). Pollyn (2003) stressed that games motivate, develop skills, abilities and strategies. Glickman as cited in Ese (2007) revealed that games enhance participation, creativity, curiosity and understanding. In addition, games enhance inquiry and help in developing scientific attitudes such as carefulness and patience. Therefore, the significances of games have made it an important instructional approach for the teaching and learning of science especially at junior secondary level.

Gender refers to the many socially and $\backslash$ or culturally constructed characteristics, qualities, behaviours and roles which different societies ascribe to females and males (Nnamani and Audu, 2005). This includes all the characteristics of men and women which a particular society assigned to each sex. It is the stratification and assignment of roles along sex line which may be culturally determined (Udaya, 2010). This certainly affect how people view or organize themselves in their society. The issue of gender influence on the acquisition of science process skills has not been conclusive (Ajunwa, 2000; Ezinwa in Mandor, 2002; Nwosu, 2002; Chukwuemeka, 
2005). Children like games a lot, but there is still gender stereotyping on the type of games played by boys and girls at home and play grounds.

In view of the foregoing, the present study was focused on evaluation of gender difference influence: effects of games on acquisition of science process skills in junior secondary school south east Nigeria.

\section{Statement of the problem}

Poor performance of students in Junior Secondary School Certificate Examination in Integrated Science now called Basic Science had consistently been recorded. This according to research findings were attributed to poor teaching methods explored by science teachers, quality of science teachers, lack or inadequate science facilities, teachers'/ learners' attitude among other factors. In order to help the students, improve in their performance, there is need to explore the efficacy of other students'- centered methods such as games in teaching Basic Science. Games as an instructional approach had been employed in teaching various subject areas especially mathematics. Unfortunately, most studies on games in Nigeria were mainly based on interest, achievement and retention in a subject like mathematics. However, there is death of literature on the use of games for the acquisition of science process skills in Nigeria. Gender issues relating to performance in Science Education tasks had not been conclusive. There is still gender stereotyping on the type of games played by boys and girls at home and play grounds among students in urban and rural schools.

Since games can be used as instructional materials and as teaching methods, there is the need to explore the efficacy of the use of games for science process skills among these students. Hence, the problem of this study posed as a question is, what are the effects of games on the acquisition of science process skills among male and female students?

\section{Purpose of the study}

This study specifically determined:

- differences on the level of the acquisition of science process skills among students that were taught with games and those taught using conventional method.

- gender differences on the acquisition of science process skills among junior secondary school I students taught using games.

\section{Significance of the study}

The findings of this study are expected to be of benefit to the students, Basic Science teachers, educational administrators, parents, teachers and training institutions.

It was expected that the findings would lay credence to the effectiveness and authenticity of the tenets of the cognitive theory of Piaget, Brunner and Vygotsky social learning theory. The findings would help to strengthen the implications of these theories in teaching and learning of science in secondary schools especially while working co-operatively and socially.

The students would benefit from the findings of this study as the efficacy of the findings might enhance the student's active participation in science which may help in improving the understanding of science process skills and Basic Science better. It may also help students to spend their leisure time wisely if they will continue to play the games after classroom activities.

\section{Scope of the study}

This study was conducted using Junior Secondary School students (JSS1) in Enugu Education zone of Enugu State. The study was limited to Enugu Education zone because it was found out that games are not commonly used for science teaching in this zone. In investigating the effects of games on the acquisition of some Basic and some Integrated Science process skills, junior secondary school I students were used for the study. This was because the units under living and non-living things used for this study are covered in JSS 1 curricula content.

\section{Research questions}

The following research questions guided the study.

1. What are the mean science process skills acquisition scores of various skills of students when taught using games compared to those taught using conventional method?

2. What are the mean science process skills acquisition scores of boys and girls when taught using games?

\section{Hypotheses}

The following null hypotheses were tested at 0.05 level of significant.

H0 $0_{1}$ : There is no significant difference in the mean science process skills acquisition scores of students when taught using games compared to those to be taught using conventional method. 
$\mathrm{HO}_{2}$ : There is no significant difference in the mean science process skills acquisition scores of boys and girls when taught using games.

H03 $_{3}$ : There is no significant interaction effect of the instructional methods and gender on the level of science process skills acquisition on the students when taught using each of the two teaching methods.

\section{RESEARCH METHOD}

\section{Design of the study}

The quasi-experimental design was used for this study. This is because intact classes were used to minimize Hawthorne effect and disruption of normal classes. Specifically, the non-randomized control group Pre-Test-PostTest design was used to ensure homogeneity of groups (Smith, 2009). The intact classes were randomly assigned to treatment and control groups. The non-randomized control group design was represented symbolically thus:

\section{Grouping} Experimental Control Key:
Pretest

$\mathrm{Q}_{1}$

$\mathrm{Q}_{1}$

Pretest

Post-Test

Treatment

no treatment

\subsection{Area of the study}

The study was carried out in Enugu State. Enugu State has six Education Zones which include Agbani, Awgu, Enugu, Nsukka Obollo-Afor and Udi Education Zones. Enugu Education Zone was chosen for the study. This is made up of Enugu North and Isi-uzo local government areas. These areas were chosen because many schools are located in the zone. This would result to a lot of students and teachers benefiting from the study. Also, the primary occupation of majority of people there, is farming and acquisition of science process skills wound enable them solve the farming problems that might confront them.

\subsection{Population of the study}

The population of this study consisted of the entire Junior Secondary School, Basic Science students one (JSS 1) of the thirty-five (35) public secondary schools in Enugu Education Zone. Twenty-five (25) of the public schools were located in the urban metropolitan while ten (10) schools were located in the rural area. These schools were five (5) single male sex schools and fourteen (14) single female sex schools and sixteen (16) co-educational schools. The total number of JSS1 students in Enugu Education Zone was six thousand, nine hundred, and twenty-six $(6,926)$. Out of these, two thousand seven hundred and twenty $(2,720)$ were boys while four thousand two hundred (4200) were girls. There was also one thousand four hundred and thirty $(1,430)$ teaching staff in Enugu Education Zone (Planning, Research and Statistic Unit Enugu State Post Primary School Management Board (PPSMB), 2010).

\subsection{Sample and sampling technique}

The sample for the study was one hundred and sixty (160) Basic Science students and four Basic Science teachers from co-education secondary schools in Enugu Education Zone of Enugu state. Stratified random sampling was employed to obtain the schools used for the study. The sixteen (16) co-educational schools in Enugu Education Zone were stratified into urban metropolitan and rural schools. Two schools were purposively selected from each stratum (urban and rural) and were randomly assigned to experimental and control groups. Hence in each location (one from each school) two intact classes of JSS 1 students was chosen using purposive sampling and randomly assigned to experimental and control groups. Therefore, a total number of four (4) intact classes of JSS 1 students were chosen for the study. The choice of the teachers was dependent on the class selected since the class teachers were used in teaching both experimental and control groups.

\subsection{Instruments for data collection}

The instruments used for the study was the Test of Science Process Skills Acquisition Test (TOSPSAT). The instruments were used as pretest for the purpose of assessing students' entry behaviour on the acquisition of science process skills. The same instruments were used at the end of the instruction as Post-Test for the purpose of measuring the level of science process skills acquisition among the students. However, items were reshuffled.

\subsection{Development of instruments}

The TOSPSAT was designed from the selected topic $\backslash$ content (living and non-living things) in the JSS1 Basic Science Curriculum. The TOSPSAT consists of 16 practical test items and 9 multiple choice items. The responses of the subjects on TOSPSAT was scored four (4) marks each for both practical and multiple-choice test items for 
the correct answer.

\subsection{Validation of the instruments}

The instruments were given to four (4) experts in science education, two (2) science educators (measurement and evaluators) and two (2) experienced integrated teachers for face and content validation. The validators validated the items in terms of proper wordings of the items, clarity of instrument to the subjects and for appropriateness and adequacy of the item. For the content validation of the TOSPSAT a test blue print was prepared in the relevant content and science process skills. The items that measured science process skill were used, because of the significance of its acquisition at JSS level. Initially forty (40) items were developed but after validation it was reduced to twenty-five (25) based on the comments made by the validators.

\subsection{Trial testing for reliability of the instruments}

The reliability of TOSPSAT was done using Kuder-Richardson formula 20 (K-R 20). This is because the instrument was dichotomously scored. The reliability of TOSPSAT was determined through trial testing of the instruments which was carried out using JSS 1 students of a school situated outside the environment of the study for the purpose of reliability. The items were administered to co-education school in Enugu South local government area. The reliability coefficient obtained was 0.84 . The games were also trial tested and improvement was made on the games that were difficult for the students to play.

\subsection{Administration of the instruments}

The items were administered twice, before and after the experiment by the research assistants that were the class teachers teaching the classes selected. The same test items were administered as pretest and Post-Test. However, the items in the pretest were reorganized in Post-Test. This was to make the items for test look different to the students.

\subsection{Initial group difference}

To control this variable, the control for the non-equivalent of intact classes was randomly composed; analysis of covariance (ANCOVA) was employed to reduce the disparity. The Pre-Test scores were used as a covariate to the Post-Test scores in an ANCOVA.

\subsection{Testing effect}

The subjects in the experimental and control groups were taught the same content areas using the same length of time and examples. The Pre-Test and Post-Test were administered to all the streams at the same time. The question papers were retrieved from every student at the end of the Pre-Test and only the scripts for those subjects were scored. The students scored scripted were not returned to them until the end of the experiment.

\subsection{Method of data analysis}

The research questions were answered using mean and standard deviation. ANCOVA was used for testing hypotheses at $\mathrm{P}<0.05$ level of significance. ANCOVA was used to test the hypotheses in order to get the required precision of the data obtained in the experimental group and to remove biases that may arise in using intact groups.

\section{Results}

\subsection{Research question 1}

What is the mean science process skills acquisition scores of students taught using games compared to those taught using conventional method?

Table 1 (a\&b): Mean Science Process Skills Acquisition Scores and Standard Deviation of Students Taught Using Games and Conventional Methods of Teaching.

Table 1 (a): Pre-Test

\begin{tabular}{|c|c|c|c|c|c|c|c|c|c|c|c|c|c|c|c|c|}
\hline \multirow[t]{2}{*}{ Groups } & \multicolumn{2}{|c|}{ Observing } & \multicolumn{2}{|c|}{ measuring } & \multicolumn{2}{|c|}{ classifying } & \multicolumn{2}{|c|}{ inferring } & \multicolumn{2}{|c|}{ Predicting } & \multicolumn{2}{|c|}{ Communicating } & \multicolumn{2}{|c|}{ hypothesizing } & \multicolumn{2}{|c|}{ Experimenting } \\
\hline & 胥 & के & हี & 卷 & 䒕 & 周 & 荧 & 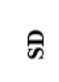 & 䒕 & 卷 & 苋 & 卷 & 䒕 & 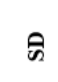 & 芯 & 卷 \\
\hline Experimental & 0.80 & 0.67 & 0.35 & 0.59 & 0.31 & 0.56 & 0.45 & 0.64 & 0.22 & 0.58 & 0.09 & 0.43 & 0.35 & 0.66 & 0.26 & 0.53 \\
\hline Control & $0 . .81$ & 0.67 & 0.41 & 1.07 & 0.43 & 0.85 & 0.78 & 1.43 & 0.29 & 0.66 & 0.33 & 0.93 & 0.40 & 1.02 & 0.15 & 0.39 \\
\hline
\end{tabular}


Table 1 (a): Post-Test

\begin{tabular}{|c|c|c|c|c|c|c|c|c|c|c|c|c|c|c|c|c|}
\hline \multirow[t]{2}{*}{ Groups } & \multicolumn{2}{|c|}{ observing } & \multicolumn{2}{|c|}{ measuring } & \multicolumn{2}{|c|}{ Classifying } & \multicolumn{2}{|c|}{ Inferring } & \multicolumn{2}{|c|}{ Predicting } & \multicolumn{2}{|c|}{ communicating } & \multicolumn{2}{|c|}{ hypothesizing } & \multicolumn{2}{|c|}{ experimenting } \\
\hline & हี & 官 & 䒕 & 周 & 䒕 & \% & ᄅ્ّ & के & 䒕 & 光 & 芯 & \% & 䒕 & ซ & 䒕 & 卷 \\
\hline Experimental & 4.81 & 1.71 & 2.50 & 1.02 & 3.72 & 1.52 & 2.62 & 1.05 & 2.60 & 1.05 & 2.35 & 1.15 & 2.20 & 1.16 & 2.23 & 1.20 \\
\hline Control & 1.50 & 0.81 & 0.93 & 0.89 & 0.98 & 0.91 & 0.90 & 0.72 & 0.77 & 0.92 & 0.55 & 1.03 & 0.55 & 0.71 & 0.38 & 0.70 \\
\hline
\end{tabular}

Table 1(c): Summary of the aggregate score

\begin{tabular}{ccccc}
\hline Groups & & Pre- Test & Post- Test & Gain score \\
\hline Experimental & No of students (N) & 80 & 80 & 44.10 \\
& Mean & 9.10 & 53.20 & 7.75 \\
Control & Std. Deviation & 5.20 & 80 & 5.80 \\
& No of students (N) & 80 & 17.40 & 7.44 \\
\hline
\end{tabular}

Results on Table 1(a) indicated that Pre-Test scores for both groups (experimental and control) were low for each of the science process skills studied (all were below 1.0) and the aggregate science process skills were 2.83 for experimental and 3.61 for control respectively. The standard deviation for the two groups for Pre-Test were also low, for instance $(0.53)$ and $(0.39),(0.35)$ and $(0.41)(1.71)$ and $(0.56)$ and $(0.85)$ and so on for the experimental and control groups respectively. This showed homogeneity in the cognitive ability levels of the two groups. For the Post-Test scores, results show that the mean aggregate score of 6.54 for the control group and 23.03 for the experimental group (Table 1b). Thus, the gain score for the control group after being taught using conventional method was 5.80 while that of the experimental group taught using games was 44.10 . While the standard deviation for the Post-Test were 7.44 for control and 7.75 for experimental group. Therefore, the difference was as a result of treatment (the use of games). Hence games enhanced the acquisition of science process skills. For the individual score's games enhanced scores (ll. However, the students scored higher for the skills of observing (4.81) then classifying (3.72) followed by inferring (2.62), predicting (2.60), measuring (2.50), communicating (2.35), Experimenting (2.23) and hypothesizing (2.20).

The results also showed that science process skills are better acquired when games are employed in teaching. For the experimental group the mean standard deviation for the Pre-Test score (5.20) and post- test score (7.75) were close and low whereas in the Post-Test the standard deviation was a bit higher than that of the Pre-Test. This also indicates homogeneity of groups in cognitive ability.

The implication is that treatment enhanced science process skills acquisition scores among JSS students and the acquisition scores of observing and classifying were the highest. For the control group the mean deviation for the Pre-Test and Post-Test were low and close showing homogeneity in cognitive ability. These findings also showed that for Pre-Test students in the control group scored low in science process skills acquisition scores in the individual skills studied and the aggregate scores was higher than those in the experimental group but after the Post-Test those taught using games scored higher in all the skills studied.

Hypothesis 1: There is no significant difference in the mean science process skills acquisition scores of students when taught using games compared to those taught using conventional method.

Tables 2: Analysis of Covariance (ANCOVA) on Students Mean Science Process Skills Acquisition Scores by Method of Group and Gender (for hypotheses 1 \& 3)

\begin{tabular}{ccccccc}
\hline $\begin{array}{c}\text { Source of } \\
\text { variance }\end{array}$ & $\begin{array}{c}\text { Type 111 sum of } \\
\text { squares }\end{array}$ & $\begin{array}{c}\text { Degree of freedom } \\
\text { (DF) }\end{array}$ & $\begin{array}{c}\text { Mean } \\
\text { squares }\end{array}$ & F & Sig. & Remark \\
\hline Corrected model & 25865.46 & 4 & 6466.36 & 113.54 & .00 & \\
Intercept & 23930.69 & 1 & 23930.69 & 420.19 & .00 & \\
Pre-Test & 103.93 & 1 & 103.93 & 1.82 & .18 & \\
Group & 24780.6 & 1 & 24780.60 & 435.12 & .00 & $\mathrm{~S}$ \\
Gender*(sex) & 1.32 & 1 & 13.27 & .23 & .63 & \\
Group sex & 53.34 & 1 & 53.34 & .93 & .33 & NS \\
Error (Residual) & 4271.33 & 75 & & & & \\
Total & 129824.00 & 80 & & & & \\
Corrected Total & 30136.80 & 79 & & & & \\
\hline
\end{tabular}

R Squared $=.858$ (Adjusted R Squared $=.851$ ).

The result on Table 2 suggest that treatment (games) is a significant factor on students' science process skills acquisition scores in Basic Science. There is therefore, a significant difference between the mean science process skills acquisition scores of the experimental and control groups as calculated $F$ value of 435.12 exceeds the $F$ value 
of .00 at $\mathrm{P} \leq 0.05$. The null hypothesis $\mathrm{Ho}_{1}$ of no significant difference is rejected. This implies that there is a significant difference in the mean science process skills acquisition scores of subjects exposed to game and those who were not exposed to games. The experimental group scores higher than the control group in the individual science process skills acquisition test (TOSPSAT). Therefore, the early observation made in Table 1(a,b\&c) was not due to chance but due to treatment.

\subsection{Research question 2}

What are the mean science process skills acquisition scores of boys and girls when taught using games?

Table 3(a\&b): Mean and Standard Deviation of Science Process Skills Acquisition Scores of Male and Female Students when Taught with Games

Table 3(a): Pre-Test and Post-Test

\begin{tabular}{|c|c|c|c|c|c|c|c|c|c|c|c|c|c|c|c|c|}
\hline \multirow[t]{2}{*}{ Sex } & \multicolumn{2}{|c|}{ Observing } & \multicolumn{2}{|c|}{ Measuring } & \multicolumn{2}{|c|}{ Classifying } & \multicolumn{2}{|c|}{ inferring } & \multicolumn{2}{|c|}{ Predicting } & \multicolumn{2}{|c|}{ communicating } & \multicolumn{2}{|c|}{ hypothesizing } & \multicolumn{2}{|c|}{ experimenting } \\
\hline & $\stackrel{\Xi}{\Xi}$ & 命 & 䒕 & 命 & 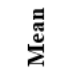 & 命 & 苋 & 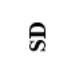 & 䒕 & 命 & Еี & ڤิ & ᄅี้ & है & 䒕 & 穴 \\
\hline $\begin{array}{c}\text { Pre-Test } \\
\text { Male }\end{array}$ & 0.72 & 0.71 & 0.19 & 0.47 & 0.23 & 0.44 & 0.51 & 0.66 & 0.25 & 0.68 & 0.00 & 0.00 & 0.44 & 0.77 & 0.32 & 0.58 \\
\hline $\begin{array}{l}\text { Pre-Test } \\
\text { Female }\end{array}$ & 1.55 & 1.87 & 0.37 & 0.60 & 0.41 & 0.63 & 0.51 & 0.72 & 0.30 & 0.56 & 0.16 & 0.53 & 0.41 & 0.62 & 0.34 & 0.58 \\
\hline $\begin{array}{c}\text { Post-Test } \\
\text { Male }\end{array}$ & 3.74 & 1.70 & 3.21 & 1.25 & 2.79 & 0.81 & 2.41 & 1.10 & 2.63 & 1.64 & 2.14 & 1.11 & 2.10 & 1.20 & 2.10 & 1.15 \\
\hline $\begin{array}{c}\text { Post-Test } \\
\text { Female }\end{array}$ & 3.93 & 1.64 & 3.85 & 0.73 & 2.77 & 0.67 & 2.43 & 0.90 & 2.44 & 1.01 & 2.38 & 1.29 & 1.50 & 0.79 & 2.14 & 1.25 \\
\hline
\end{tabular}

Table 3(b): Summary of aggregate score

\begin{tabular}{ccccc}
\hline Sex & & Pre-Test & Post-Test & Gain score \\
\hline Male & No of Students (N) & 20 & 20 & 43.60 \\
& Mean & 9.20 & 52.80 & \\
Female & Std. Deviation & 5.52 & 8.26 & 44.60 \\
& No of Students (N) & 20 & 20 & \\
\hline
\end{tabular}

The results on table 3 above show that the Pre-Test for males in the experimental group was low for each of the science process skills studied all were below 1.0 and the aggregate science process skills were 2.56. However, the mean science process skills acquisition was 9.20 and the standard deviation for Pre-Test was 5.52 and the mean gain score was 43.60. Whereas, the Pre-Test for the females in the experimental group was below 1.0 expect the skill of observation 1.55. The mean aggregate for science process skills was 3.65 while the mean score was 9.00 and the standard deviation of Pre-Test was 5.00. For the Post-Test scores, results show that the males in the experimental group scores above 2.0 for the science process skills studied, the highest was skill of observing (3.74) then measuring (3.21), followed by classifying (2.29) then predicting (2.63). The mean aggregate for all the skills was 21.34. More so, the mean science process skills acquisition score for the boys was 52.80 whereas the standard deviation was 8.26. While girls taught using games scores above 2.0 in all the skills studied expect hypothesizing (1.50). The mean aggregate for the skills is 23.44 while mean score was 53.60 with the standard deviation of 7.38. The mean gain scores was 44.6, which was slightly higher than that of the boys (43.60). Notice that the Pre-Test scores, for both groups are different in favour of girls (1.39). But in Post-Test scores (3.12). Although the girls score higher than boys both in Pre-Test and Post-Test, the gain score differ due to treatment, Post-Test is greater (3.12 1.0). The above observations imply that male and female students exposed to game teaching method scored higher in science process skills acquisition. But girls exposed to games scored slightly higher in the skills of observing, measuring and inferring while the males scored slightly higher in the process skills of classifying, predicting and hypothesizing. This is because both male and female students exposed to treatment (games) scored higher in the POST-TOSPSAT in all the individual skills. Again, the standard deviation for both the Pre-Test and Post-Test scores were low and close to each but that of the Post-Test were higher showing homogeneity in cognitive ability in all the groups.

Hypothesis 2

There is no significant difference on the mean science process skills acquisition scores of boys and girls when taught using games. 
Table 4

ANCOVA Result for the Mean Science Process Skills Acquisition Scores of Male and Female Students in Experimental Group

\begin{tabular}{ccccccc}
\hline Source & Type III Sum of Squares & Df & Mean Square & F & Sig. & Remark \\
\hline Corrected Model & 286.16 & 2 & 143.08 & 2.47 & .099 & \\
Intercept & 31964.42 & 1 & 31964.42 & 551.26 & .000 & \\
Pre-Test & 249.59 & 1 & 249.59 & 4.30 & .045 & \\
Sex & 21.66 & 1 & 21.66 & .37 & .545 & NS \\
Error & 2145.44 & 37 & 57.99 & & & \\
(Residual) & & & & & & \\
& & & & & & \\
Total & 115216.00 & 40 & & & & \\
Corrected Total & 2431.60 & 39 & & & &
\end{tabular}

R Squared $=.118$ (Adjusted R Squared $=.070)$.

The result on Table 4 showed that treatment (Games) is not significant on the mean science process skills acquisition scores of male and female students in the experimental group. It was observed that the calculated $\mathrm{F}$ value of .37 is not significant at .54 . This value is greater than the 0.05 probability level set for the study. Based on this, the null hypothesis $\mathrm{HO}_{2}$ is accepted. It is therefore concluded that there is no significant difference in the mean science process skills acquisition scores of male and female students when exposed to games.

\section{Hypothesis 3}

There is no significant interaction effect of the instructional methods and gender on the level of science process skills acquisition on the students taught using each of the two teaching methods.

From Table 4 it was observed that interaction effect of methods and gender of the subjects on science process skills acquisition scores was not significant. From the table on page 72 the F calculated value was .93 which is greater than the $\mathrm{F}$ critical value of .33 at $\mathrm{P} \leq 0.05$. Thus, the null hypothesis $\mathrm{H}_{4}$ is rejected. This means that treatment has effect in enhancing acquisition of science process skills. The effect was constant and the value did not vary due to gender. Thus games (treatment) did not combine with gender to affect science process skills acquisition score. Therefore, there is no significant interaction effect between gender and instructional methods on science process skills acquisition score of the JSS Basic Science students. The result on table 2 on the mean science process skills acquisition scores of male and female students confirmed this where the male and female students exposed to game teaching method scored higher in science process skills acquisition.

\section{Discussion}

Table 1 showed that the mean science process skills acquisition scores of students in both control and experimental groups in the Pre-Test were close before the commencement of the treatment, showing homogeneity of group in intellectual ability. But after the treatment the students in the experimental group had higher mean science process skills acquisition scores in all the skills studied but the skill of observing was highest then classifying followed by predicting and measuring than students in control group. These skills are basic science process skills which are expected to be acquired at this educational level. Notice that higher order skills (hypothesizing and experimenting) were acquired in this educational level after the treatment. The mean deviation in scores was close to each other. The mean gain score was also high after the treatment indicating the efficacy of games as activity-based instructional procedure in science process skills acquisition score. This showed that active participation of the students during lesson enhanced science process skills acquisition scores among the students. This was further confirmed in Table 2 which revealed that treatment was a significant factor on students mean science process skill acquisition scores since $f=435.12$. This showed that at 0.05 level of significant that $f=435.12$ is less than 0.05 . Therefore, the null hypothesis of no significant difference is rejected. So, game as the main effect is significant on science process skills acquisition scores of students.

Furthermore, the students exposed to conventional method of teaching had low mean science process skills acquisition score. This is because the data obtained indicate that the scores are low and very close to each other both in Pre-Test and Post-Test. The mean gain score was also low. Hence, students who were taught Basic Science using games scored higher in science process skills acquisition test than those taught using the conventional method. The findings support the findings of other previous researchers such as Nwosu (1991) where teachers' sensitizations enhanced the level of acquisition of science process skills among Biology students. The findings also confirmed the result of Ibe (2004) that Biology students exposed to guided inquiry method perform significantly better than those taught using demonstration and conventional method. Again, the result is in line with the finding of Chukwuemeka (2006) that revealed that science process skills were better acquired through 
active participation of pupils in the use of resources than conventional method. Hence, new method of teaching science as experimental treatment proved better than the use of conventional method. Mandor (2002) revealed that constructivism which is activity oriented enhance skills acquisition among students than those exposed to conventional method of teaching. Therefore, active participation of the students in games during Basic Science lesson enhanced learning as was propounded by Brunner (1966).

Furthermore, the results on Table 3 on gender and acquisition of science process skills showed that both male and female students in the experimental group benefited because the respective mean Post-Test science process skills acquisition scores was higher than that of the Pre-Test. For instance, the male students exposed to games had Pre-Test mean science process skills acquisition score of observing 0.72 while the Post-Test mean score for observing was 3.74. This implies a mean score gain of 3.02. Similarly the female Pre- TOSPSAT mean score in the same group for observing was 0.81 while the corresponding POST- TOSPSAT mean score of observing was 4.81 thereby giving the mean gain score of 4.00 .

More so, the mean gain score obtained after the treatment showed that the gain score was very high after treatment. In addition, the deviation between scores was close in both Pre-Test and Post- Test but, in Post-Test the distance between scores was also close but higher than that of the Pre-Test. The implication is that treatment (games) enhanced science process skills acquisition score This was further confirmed by the ANCOVA results in table 5 which revealed that gender was not a significant factor in science process skills acquisition score in Basic Science since $\mathrm{f}=\cdot 37$. This shows that at 0.05 level of significant that the mean $\mathrm{F}=.37$ more than 0.05 . So the null hypothesis of no significant is rejected. This implies that gender had no significant effect on students' science process skills acquisition scores. Therefore, the slight difference in the mean science process skills acquisition scores between male and female students is not significant among male and female students exposed to the treatment. Hence the different was not significant. This finding is in support of Chukuwemeka (2006) that there is no significant difference in the mean science process skills task among male and female pupils exposed to material resources. The finding is also in support of Nwosu (2001) that there is no difference in the mean scores of SS1 students' in process skills acquisition due to gender and that the slight difference that could exist could be caused by gender stereotyping and socialization process or outside the home. However, games irrespective of gender stereotyping influenced science process skills acquisition scores of male and female students in this study. In addition, the finding is in support of Ivowi (1993) that there was no difference in the achievement among students as a result of sex in a study on achievement level in understanding physics. The result confirmed the finding of Aiyedun (2000) study on influence of sex differences of students on achievement that revealed that performance in mathematics did not depend on sex. The finding is also in support of Ukwungwu (2002) that gender performance in Integrated Science is not significant on the metal analytical performance of students in Integrated Science. But this study was contrary to the finding of Obodo (1997) that there was significant difference between male and female students on performance of students in Mathematics. Again, Obi (2006) result on the effect of two problem solving models on students' achievement revealed that male students tend to achieve significantly higher than their female counterparts when taught with the same method.

It was also observed from Table 2 that interaction effects of methods and gender on science process skills acquisition on the students' scores was not significant that is $\mathrm{F}=.93$ at 0.05 level of significance $\mathrm{F}=.93$ is more than 0.05. The null hypothesis of no significant interaction effect was rejected. The result on table 1 showed that the mean gain score was high after treatment which implies that treatment enhanced science process skills acquisition score. Therefore, there was no significant interaction between the main effect (games) and gender. This result is in support of the finding of Abonyi (1999) that there was no significant interaction between Video and audio radiograph and gender in achievement in science and retention. The finding is also in support of Iloputaife (1995) that there was no significant interaction between instructional method and gender in the study on practical work method on physics process skills attainment among students. The finding also confirmed the finding of Chukwumemeka (2006) that gender did not combine with manipulation of material resources to affect pupils' acquisition of science process skills. However, according to Ibe (2004) differences in performance may be attributed to teacher factor, pupils' personal interest in the subject etc. Since, there is no interaction due to teaching method and gender in this study. It could be assumed that the differences observed in the science process skills acquisition scores among students in this study may be attributed to the game teaching method which enhanced mean science process skills acquisition scores of male and female students.

\section{Conclusion}

From the result of this investigation, the following conclusion were made

1. Active participation of students and co-operation during the science lesson through game approach promoted science process skills acquisition.

2. There were no interaction effects between the teaching method and gender and any differential effects observed might be as a result of instructional method used not due to gender. 


\section{Educational Implications of the Study}

The findings of this implies that teachers should start learning and adopting the use of games in teaching school students especially at Junior Secondary level. Focus should be on use of games that will enhance students' acquisition of science process skills.

Students should now be aware of the use of games in learning science concept because it is learner's centered. Games will avail students of the opportunity of studying beyond lesson periods. There is need for regular reorientation of teachers on development and use of games that enhance science process skills acquisition through seminars, workshops and conferences by every tier of government.

The findings of the study is significant to the curriculum planners on the need to restructure and infuse games as teaching method in the science curriculum and in teacher Education Programme such that class room activities do not only based on process based learning, but also sustain students' learning and interest throughout and beyond the lesson periods. This finding will also assist the curriculum planners on the need for the provision of relevant games as teaching methods and instructional material for effective teaching and learning. The inclusion of games in the curriculum will make learning friendly and more meaningful.

\section{References}

Abonyi, O.C. (1999). Effects of an Ethno-Science based Instruction Package on Students' conception of scientific phenomena and Interest in Science. An Unpublished Ph.D. Desertification. Faculty of Education, University of Nigeria, Nsukka.

Aiyedun, T.O. (2000). Influence of sex differences of students on their achievement in secondary school mathematics Journal of Mathmatics Association of Nigeria 25(1), 109-113.

Ajunwa, C.A. (2000). Acquisition of Physics Process Skills by Secondary School Students. An Unpublished Ph.D. Desertification. Department of Science, Faculty of Education, University of Nigeria, Nsukka.

Brunner, J.S. (1966). The process of Educational Psychology. New Delhi, Van Educational books.

Chukwuemeka, P.C. (2005). Effects of Mode Presentation of Material Resources on the Acquisition of Science Process Skills among Primary School Pupils. Unpublished M.Ed. Thesis, Department of Science Education, University of Nigeria, Nsukka.

Finely, F.N. (1983). Science Process. Journal of Research in Science Teaching 20(1), 47-53.

Harbor Peters, U.F.A. (2001). Unmasking some aversive aspect of school Mathematics and strategies for averting them an inaugural lecture presented in University of Nigeria, Nsukka, Enugu, Snaap Press Limited.

Ibe, E. (2004). Effect of Guided Inquiry and Demonstration on Sciences Process Skills acquisition among biology secondary school student. Unpublished M.Ed. Thesis, Faculty of Education, University of Nigeria, Nsukka.

Iloputaife, E.C. (1995). The effect of investigational practical work method on practical physics process skills attainment level of J.S.S. students in Arinze, F.O (ed). The Nigeria secondary school system input process and output. Onitsha, Hornbill publisher 346-351.

Iloputaife, E.C. (1996). Method and Location as Factors in school's cognitive achievement on physics unpublished M.Ed. thesis. Faculty of Education, University of Nigeria, Nsukka.

Ivowi, U.M. (1993). Achievement level in understandings physics concepts in secondary school. Journal of Research in Curriculum 17(14), 307-312.

Lawrence, F. (2006). http://www.sciencein school.org/2006/issue/play. Assessed on 17/04/2020.

Mandor, A.K. (2002). Effects of constructivist based instructional model on acquisition of science process skills among Junior Secondary School Students. Unpublished M.Ed. thesis, Faculty of Education, University of Nigeria, Nsukka.

Nnamani, B.I. \& Audu, U.D. (2005). Breaking Gender Barriers in Science, Technology \& Mathematics Education (STME): Paper presented at Department of Science Education Abia State University Uturu $20^{\text {th }}-23^{\text {rd }}$ September.

Nwosu, A.A. (2002). Inquiry Skill Acquisition for Enhancing Women's participation in sustainable Development implication for Science Education. STAN 43 ${ }^{\text {rd }}$ Conference proceedings HEBN 94-78.

Nwosu, A.A. (1991). The effect of Teacher Sensitization on Secondary School Students' level of Acquisition of Science Process Skills. Unpublished Ph.D. Dissertation. Faculty of Education University of Nigeria, Nsukka.

Nwosu, A.A. (2001). Gender and Acquisition of Science Process Skills among Secondary School Students implication for Science Teaching 42 ${ }^{\text {nd }}$ STAN Annual conference proceedings HEBN 206-209.

Obi, C.N. (2006). Comparative Study of the Effects of Two Problem-Solving Models on Students Achievement and Interest on Word Problems in Algebra. An Unpublished M.Ed. thesis University of Nigeria, Nsukka.

Obodo, G.C. (1997). Principles and Practice of Mathematics Education on the Performance of Junior Secondary School Students. An Unpublished Ph.D. thesis University of Nigeria, Nsukka.

Pollyn, B.I. (2003). Picco Games: Means of Effective Information \& Communication in Schools and Homes. STAN $44^{\text {th }}$ Conference Proceedings. HEBN.109-110.

Udaya, C.O. (2010). Gender Issues in International Politics and the MDGs. Journal of Arts and Social Sciences 
Review. Federal College of Education, Eha-Amufu 3(1), 177-184.

Ukwungwu, J.O. (2002). Gender Differences Study of Performance in Integrated Science. A summary of studies conducted in Nigeria. Journal of Science Teachers Association of Nigeria 37 (1\&2), 55-59.

Umo, U.C. (2001). Effects of Games on Achievement and Interest of Junior Secondary School Students in Igbo Grammar. Unpublished Ph.D. Dissertation, Faculty of Education, University of Nigeria, Nsukka. 